\title{
Preface
}

This book has been long in coming. As its subtitle suggests, it represents ideas that I have, for many years, been pondering over. As such, different parts, in different ways, have been the subject of seminars, workshops, and lectures in any number of places. There are too many to recognize individually here. But if a reader sees something in the book and remembers a discussion about it in his or her school, I mean today to let that reader know that I too probably remember and am grateful.

There are, however, some more proximate helpers who must be mentioned. Robert Post, the dean of the Yale Law School, has been unfailing in his support, and so have my colleagues at that school. These friends, both in a recent workshop and individually, have been more than generous in their criticisms, suggestions, and encouragement. That they continue to treat this sometime scholar and oft-time judge as one of their own means more to me than I can say.

John Donohue and the American Law and Economics Association, and Alain Marciano and Giovanni B. Ramello, also 
deserve special note. The first awarded me the Coase Medal and thereby led me to pull together the thoughts that underlie the last two chapters of this book, to which, incidentally, both John Donohue and my colleague and friend Bruce Ackerman made particular contributions. The second organized a conference titled "Law and Economics: The Legacy of Guido Calabresi," published in 77 Journal of Law and Contemporary Problems 2 (2014), which led to the structuring of the ideas which are the core of what, here, is chapter 6.

A book like this could never have been written were it not for the patience and help of my longtime assistant Susan Lucibelli. Her name properly appears in all but one of my books, as she and I have been working together for more years than can decently be said. My law clerks past-Cat Itaya, Luke Norris, David Wishnick—and present-Nate Cullerton, Eric Fish, Kevin Lamb-deserve special mention. They have been tireless in their editing, footnoting, and bluebooking, and they did all this without a whimper on top of all their work on my judicial cases and opinions. It is a joy to have people around me like them and my other assistant Marge Greenblatt. Finally, and as always, my deepest thanks go to my wife, Anne, who for more than fifty-four years has been my loving companion, wisest critic, and dearest friend.

One more thing needs to be said. This book is not a "scholarly" book in the ordinary sense. It does not purport to canvas the literature or to recognize all or most who have written on the various topics that I discuss. That is what I was inclined to do when I was a full-time scholar and teacher. My reluctance to deviate from that mode, together with the fact that I do not have the time to undertake that level of research while also being a judge, explains the long delay in this book's "coming." Many people, however, have urged me to put into 
writing, before dotage sets in, ideas that have been percolating in my mind for years. The result is this book. To the extent that the book fails to give proper recognition to scholars who have preceded me with respect to some of the things I here write, I apologize, and I hope that, as a result of this book, their own scholarship may become better known even outside of their own particular fields. I say this in general, but especially as to those practitioners of Welfare Economics who, I do not doubt, have foreshadowed me, but whose work has, unfortunately, not been much noticed by those other practitioners to whom this book is distinctly addressed, the Lawyer-Economists. It is some of these who, in my judgment, on too many occasions proffer criticisms of the existing legal world on the basis of economic theory that does not, without more, justify that criticism. 
This page intentionally left blank 


\section{The Future of Law and Economics}


This page intentionally left blank 